\title{
What's in a Name Case? Some Lessons for the Debate on the Free Movement of Same-Sex Couples within the EU
}

(German Law Journal, forthcoming 2016)

Martijn van den Brink*

\footnotetext{
* Phd Researcher, European University Institute; Michigan Grotius Research Scholar, University of Michigan. Email: martijn.vd.brink@gmail.com. I want to thank the participants of the Workshop for Young EU Lawyers organised by LSE, in particular Floris de Witte and Jacco Bomhoff, and the participants of the EUI Doctoral workshop on European law, in particular Loïc Azoulai, for all their useful critiques and comments. I also want to thank Filipe Brito Bastos for his comments during the different stages of writing this article. All opinions expressed and remaining errors are mine.
} 


\section{A. Introduction}

Among the EU Member States, a diverse set of laws concerning same-sex partnerships can be found. While a number of Member States have opened up the institute of marriage to same-sex couples, ${ }^{1}$ others have adopted constitutional provisions that protect 'traditional' marriage. ${ }^{2}$ Some Member States have introduced registered partnerships, which sometimes bring same-sex couples into a position equal to opposite-sex couples in all but name. ${ }^{3}$ In addition to the variety of partnerships, also the rights same-sex couples are provided with differ. Not all Member States that have introduced same-sex marriage, for example, provide those couples with the same rights as opposite-sex married couples. $^{4}$

As a result of the lack of uniform rules, national administrations and courts have been confronted with the question whether or not to recognise and give legal effect to same-sex marriages celebrated in other Member States but outlawed in theirs. At times they have refused to do so. In 2004, a German court refused to recognise the same-sex marriage of a Dutch-Taiwanese couple residing in Germany, who married according to Dutch laws. ${ }^{5}$ Similar decisions have been rendered in other Member States. ${ }^{6}$ The possible harmful consequences for same-sex couples' free movement rights has given rise to concern among scholars as well as EU institutions. ${ }^{7}$ This right, after all, is likely to become less attractive if the new Member State of residence does not recognise the marriage legally celebrated in another Member State; same-sex couples are less likely to move if, as the US Supreme Court recently stated in Obergefell $v$ Hodges, their marriage "is stripped from them (...) as they travel across state lines". ${ }^{8}$

This paper engages with the debate on the free movement of same-sex couples and examines what we can and should learn from the case law on the recognition of names. It is argued here that these 'name cases' present us with valuable lessons which those arguing in favour as well as against recognition of same-sex marriages ought to consider. Since strong normative justifications can be provided for the relevant aspects of the name cases, those lessons cannot be ignored.

Through an examination of the name cases, the paper demonstrates that the questions raised by the free movement of same-sex couples are of a more complicated nature than scholars seem to have recognised. We need to more carefully distinguish, first of all, the different kind of cross-border situations that may arise, rather than adopting a one-size-fits-all argument. Secondly, we should recognise that even though EU law presupposes recognition of personal statuses acquired in other

\footnotetext{
${ }^{1}$ At the moment: France, Spain, Portugal, the United Kingdom, the Netherlands, Belgium, Denmark, Luxembourg and Sweden.

${ }^{2}$ See: Article 46 of the Bulgarian Constitution; Article 110 of the Latvian Constitution; Article 38 of the Lithuanian Constitution; Article 18 of the Polish Constitution; Article 48 of the Romanian Constitution; Article L of the Hungarian Constitution.

${ }^{3}$ Nicholas Bamforth, The Benefits of Marriage in All but Name-Same-Sex Couples and the Civil Partnership Act 2004, 19 Child \& Family Law Quarterly 133 (2007).

${ }^{4}$ France is a case in point.

${ }^{5}$ For a reference to this case see: Johan Meeusen, Instrumentalisation of Private International Law in the European Union: Towards a European Conflicts Revolution?, 9 European Journal of Migration and Law 287, 297 (2007).

${ }^{6}$ For references to cases in Eastern Europe see: Adam Bodnar and Anna Śledzińska-Simon, Between Recognition and Homophobia: Same-Sex Couples in Eastern Europe, in SAME-SEX COUPLES BEFORE NATIONAL, SUPRANATIONAL AND INTERNATIONAL JURISDICTION 211 (Daniele Gallo, Luca Paladini and Pietro Pustorino eds., 2014 ) 211.

${ }^{7}$ For an overview see section $C$.

${ }^{8}$ Obergefell v Hodges, 576 US _ (2015), page 6.
} 
Member States, the protection offered by EU law to same-sex couples is not as unequivocal as has at times been assumed. Take the following fictitious example, to which I will return during the remainder of this article: A Dutch-Polish homosexual couple gets married in the Netherlands, but subsequently moves to Greece where one of the partners found a job. Should Greece be placed under an obligation to recognise this marriage? And should the answer to that question depend on whether the couple was habitually resident in the Netherlands when forming a marital union, or on the strength of Greece's public policy objections against recognising same-sex marriages? And what if the couple goes back to Poland for a short while to visit the Polish national's family? Should Poland be under the same requirements as Greece? In sum, the free movement of same-sex couples raises a multitude of challenging issues, which cannot be conflated.

To assess the relevance of the names cases, this paper will start with an explanation of why precisely the name cases are relevant for the debate on the free movement of same-sex couples (B). This is followed by a brief overview of the state of the debate $(\mathrm{C})$. Hereafter, it is discussed what we should learn from the name cases. It is argued, first of all, that policies of non-recognition are suspect under EU law and that Member States can no longer unconditionally apply their private international law tools (D), but that, simultaneously, serious account must be taken of the national and constitutional identity of the Member States (E). In the last section, it is argued that the dilemma that confronts us must be recognised as a federal clash of values, which needs to be taken seriously. Some suggestions are offered as to how to the way this dilemma can be dealt with (F).

\section{B. The relevance of the names cases}

According to an American conflict of laws expert, the law on the recognition of family names "epitomizes the cultural identities underlying the most pertinent European conflict cases". 9 The position of same-sex couples brings to the fore another, perhaps even more profound clash between the cultural identities within the EU. Interestingly, the Court in the name cases assumed responsibility for determining overarching principles that determine under what conditions free movement can take place, by laying down principles for the recognition of personal statuses. Those personal statuses may comprise names, but other personal relationships, including marriage and adoption as well. ${ }^{10}$ To what extent EU law prescribes the Member States to change their traditional approach to the recognition of foreign personal statuses in one area (names) may thus certainly be relevant for other areas (including same-sex marriages).

One may contest the presumed relevance of the name cases and claim that same-sex marriages are more important than the spelling of names. Such a conviction, though understandable, is ultimately a subjective one. Such statements are likely to understate the importance of language issues within certain Member States, which may be of a higher sensitivity than the position of same-sex couples. There is one difference, however, which cannot be ignored. Contrary to a name, a marriage generally produces a wide variety of 'incidents'. ${ }^{11}$ Marriage is not merely a personal status, but one which

\footnotetext{
${ }^{9}$ Ralf Michaels, The New European Choice-of-Law Revolution, 82 Tulane Law Review 1607, 1632 (2008).

${ }^{10}$ Horatia Muir Watt, European Federalism and the "New Unilateralism”, 82 Tulane Law Review 1983 (2007).

${ }^{11}$ ANDREW KOPPELMAN, SAME SEX, DIFFERENT STATES: WHEN SAME-SEX MARRIAGES CROSS STATE LINES 93 (2006) 93.
} 
generally provides the bearer of the status with a number of incidental rights and duties, such as the right to adopt, tax benefits, or parental responsibilities. ${ }^{12}$ The free movement of same-sex couples, therefore, not only raises questions as regards the recognition of the status itself but also to which incidents of marriage same-sex couples are eligible in a Member State that has precluded same-sex couples from celebrating a marriage. It is certainly in relation to the latter question that the name cases are likely to provide only very little insight. The remainder of this article will, therefore, largely deal with the question of the recognition of the status, not so much with the rights attached to this status, although some suggestions as to the latter will be offered in the last section.

\section{The state of the debate}

It is disputed how the secondary legislation must be interpreted. At first sight, it appears obvious that Directive 2004/38 (Citizenship Directive) provides same-sex couples with better protection than the legislation it replaced. The explicit reference to the spouse in Article 10 of Regulation 1612/68 made that same-sex partners were unlikely to benefit from the protection offered by this provision at that time. ${ }^{13}$ The Citizenship Directive extended the personal scope so as to include "the spouse", ${ }^{14}$ registered partners "if the legislation of the host Member State treats registered partnerships as equivalent to marriage", ${ }^{15}$ and to "the partner with whom the Union citizen has a durable relationship, duly attested". ${ }^{16}$ There remains scepticism as to what extent the position of same-sex partners has been strengthened, however, since the initial proposal, which would have offered substantial protection, was diluted during the negotiation process. ${ }^{17}$

Notwithstanding the disputed scope of the secondary law, scholars have adopted a virtually uniform position. Remarks that it might be unwise for the ECJ to get too involved in such a sensitive matter ${ }^{18}$ are met with scepticism. ${ }^{19}$ If not on the basis of the Citizenship Directive, the ECJ should at least interpret the Treaty provisions on the free movement of Union citizens in a manner that forces Member States to recognise the personal status of marriage. Obstacles to the enjoyment of the right to free movement of same-sex couples should be removed through the application of the principle of

\footnotetext{
${ }^{12}$ To get an idea of the responsibilities and benefits that can possibly be conferred on married couples see: Obergefell $\checkmark$ Hodges, 576 US _ (2015) page 17.

${ }^{13}$ Although the Regulation could be read differently, providing the same-sex partner with protection. Andrew Clapham and JHH Weiler, Lesbians and Gay Men in the European Community Legal Order, in HOMOSEXUALITY: A EUROPEAN COMMUNITY ISSUE: ESSAYS ON LESBIAN AND GAY RIGHTS IN EUROPEAN LAW AND POLICY (KeeS Waaldijk \& Andrew Clapham eds., 1993).

${ }^{14}$ Council Directive (EC) 2004/38 (n 65), art. 2(2)(a).

${ }^{15} \mathrm{Ibid}$, art. 2(2)(b).

${ }^{16} \mathrm{lbid}$, art. 3(2)(b).

${ }^{17}$ Mark Bell, Holding Back the Tide? Cross-Border Recognition of Same-Sex Partnerships within the European Union 12 European review of private law 613 (2004); HELEN TONER, PARTNERSHIP RIGHTS, FREE MOVEMENT, AND EU LAW, 60-68 (2004); ALINA TRYFONIDOU, EU Free Movement Law and the Legal Recognition of Same-Sex Relationships: The Case for Mutual Recognition 21 Columbia Journal of European Law 195, 209-214 (2015) .

${ }^{18}$ Anne Peter van der Mei, Book Reviews, 14 Maastricht Journal of European and Comparative Law 101, 102-103 (2007).

${ }^{19}$ Katharina Boele-Woelki, The Legal Recognition of Same-Sex Relationships within the European Union, 82 Tulane Law Review 1949, 1970 (2007).
} 
mutual recognition. ${ }^{20}$ In other words, to prevent that Member States create obstacles to the exercise of same-sex couples, through the non-recognition of their partnership, EU law should require all Member States to give recognition to a marriage legally celebrated in another Member State, including those Member State where such marriages are not lawful. Taking our fictitious example from the introduction, Greece should be under an obligation to recognise the Dutch-Polish couple's same-sex marriage when they take up residence in Greece, no matter the precise circumstances. At times, this argument is further reinforced by adding a fundamental rights dimension to the discussion: not only is mutual recognition the only way to ensure the protection of fundamental rights of the same-sex couples, ${ }^{21}$ also would, analogous to the US Supreme Court's decision in Obergefell $v$ Hodges, a cautious approach be unwarranted in the face of fundamental rights' violations. ${ }^{22}$

Additionally, federal theory is used to support the case for mutual recognition. Comparative studies very well highlight the similarities of the issues faced by both the EU and the US. ${ }^{23}$ The fact that the US Constitution left the States free to determine whether or not to recognise same-sex marriages legally celebrated in other States notwithstanding, ${ }^{24}$ federal theory has been invoked to demonstrate how the EU can and should advance the liberty of its citizens by providing them with an exit option. Such an exit option would allow them to move to the Member State that suits their interests best - in this case, Member States with beneficial marital rules for same-sex couples. ${ }^{25}$ In other words, EU law should be interpreted as allowing the Dutch-Polish same-sex couple to move from Poland to the Netherland in order to take up residence there. The right to non-discrimination on the grounds of nationality would subsequently require the Netherlands, since it has decided to

\footnotetext{
${ }^{20}$ Most recently, Tryfonidou (note 17). But see also: Mark Bell, We Are Family-Same-Sex Partners and EU Migration Law, 9 Maastricht Journal of European \& Comparative Law 335, 351-352 (2002); Jorrit Rijpma and Nelleke Koffeman, Free Movement Rights for Same-Sex Couples Under EU Law: What Role to Play for the CJEU?, in SAME-SEX COUPLES BEFORE NATIONAL, SUPRANATIONAL AND INTERNATIONAL JURISDICTIONS, 455 (Daniele Gallo, Luca Paladini and Pietro Pustorino eds., 2014); Gerard-René de Groot, Private International Law Aspects Relating to Homosexual Couples, 11 Electronic Journal of Comparative Law (EJCL) 30 (2007) <http://ejcl.org/113/article113-12.pdf> accessed 19 March 2015; Türkan Ertuna Lagrand, Mutual Recognition of Same-Sex Marriages from an EU Immigration Law Perspective in EQUALITY AND JUSTICE: SEXUAL ORIENTATION AND GENDER IDENTITY IN THE XXI CENTURY, 241 (Alexander Schuster ed., 2011); Justine Quinn, Free Movement and the European Family - Falling in Love with the Common Market, in EQUALITY AND JUSTICE: SEXUAL ORIENTATION AND GENDER IDENTITY IN THE XXI CENTURY, 257 (Alexander Schuster ed., 2011).

${ }^{21}$ Matteo Bonini Baraldi, EU Family Policies between Domestic 'Good Old Values' and Fundamental Rights: The Case of Same-Sex Families 15 Maastricht Journal of European \& Comparative Law 517 (2008); Rijpma and Koffeman (note 20) 461-465.

${ }^{22}$ Obergefell v Hodges, 576 US _ (2015) pages 23-25.

${ }^{23}$ The US Supreme Court decision to legalise same-sex marriages in Obergefell v Hodges, 576 US _ (2015) has of course radically changed the situation. The Supreme Court held: "if States are required by the Constitution to issue marriage licenses to same-sex couples, the justifications for refusing to recognize those marriages performed elsewhere are undermined". For an EU-US comparison pre-Obergefell $v$ Hodges see: Adam Weiss, Federalism and the Gay Family: Free Movement of Same-Sex Couples in the United States and the European Union, 41 Columbia Journal of Law \& Social Problems 81 (2007).

${ }^{24}$ For an overview of the way federal principles interact in the case of the free movement of same-sex couples in the US, see: Koppelman (note 11); Linda J Silberman, Can the Island of Hawaii Bind the World - A Comment on Same-Sex Marriage and Federalism Values, 16 Qiunnipiac Law Review 191 (1996).

25 Dimitry Kochenov, On Options of Citizens and Moral Choices of States: Gays and European Federalism, 33 Fordham International Law Journal 156 (2009); Seth F Kreimer, Federalism and Freedom, 574 Annals of the AAPSS 66.
} 
allow same-sex couples to marry, to extend this right to non-nationals as well. Along the same lines of thought, the EU is also supposed to provide its citizens with an entry option, which allows them to move back to their Member State of origin or any other Member State with the newly acquired status. ${ }^{26}$ When interpreted as such, EU law would require Greece to recognise the marital status of the Dutch-Polish couple once they take up residence there. And so would Poland would the couple decide to go to Poland for a quick family visit.

The Member States that do not allow same-sex couples to enter into marriages are likely to reject such arguments. Particularly those Member States that have adopted constitutional provisions specifying the mixed-gender nature of marriages will oppose recognition. National administrations and courts have already decided not to give recognition to same-sex marriages legally celebrated abroad. ${ }^{27}$ While those Member States may admit that non-recognition poses an obstacle to the right to free movement, they will find that their policy of non-recognition is justified for public policy reasons. To defend their argument, those member States will find strength in Article 4(2) TEU, which requires the EU to respect the Member States' "national identities, inherent in their fundamental structures, political and constitutional".

In short, two opposing positions, broadly speaking, can be identified within the debate on the free movement of same-sex couples. None of the two, however, seems to fully take into account (the limitations to) the requirements imposed by EU law. Those supporting non-recognition ignore how suspect such policies are under EU law. Even though this might not be too surprising, also those who argue that EU law must be interpreted as forcing Member States to recognise same-sex marriages celebrated in another Member State ignore that EU law might be less unequivocal than sometimes presupposed. The importance of the principle of mutual recognition notwithstanding, EU free movement law does not necessarily provide EU citizens with an entry option that is as strong as their exit option. The insights provided by the name cases are enlightening in this respect.

\section{Beyond private international law}

The name cases undisputedly demonstrate that policies of non-recognition of same-sex marriages are suspect under EU law. Member States can no longer unconditionally apply their traditional private international law tools; account must be taken of EU legal requirements. This development is reinforced by the great autonomy granted by the ECJ to EU citizens. In the case multiple laws are applicable, they are allowed to decide which rules to benefit from. The Member States are subsequently required to recognise the individuals' decision. In the first case of interest, Garcia Avello, ${ }^{28}$ it was decided to allow EU citizens to benefit from the laws of their Member State of nationality, even when

\footnotetext{
${ }^{26}$ Kochenov (note 25) 189-195; Koen Lenaerts, Federalism and the Rule of Law: Perspectives from the European Court of Justice, 33 Fordham International Law Journal 1338, 1355-1361 (2009).

${ }^{27}$ In addition to the examples referred to in the introduction, see also: Patrick Wautelet, Private International Law Aspects of Same-Sex Marriages and Partnerships in Europe - Divided We Stand?, in LEGAL RECOGNITION OF SAMESEX RELATIONSHIPS IN EUROPE: NATIONAL, CROSS-BORDER AND EUROPEAN PERSPECTIVES $163-166$ (Katharina Boele-Woelki and Angelika Fuchs eds., 2012); Giacomo Biagoni, On Recognition of Foreign Same-Sex Marriages and Partnerships, in SAME-SEX COUPLES BEFORE NATIONAL, SUPRANATIONAL AND INTERNATIONAL JURISDICTIONS, 375-376 (Daniele Gallo, Luca Paladini and Pietro Pustorino eds., 2014).

${ }^{28}$ Case C-148/02 Garcia Avello [2003] E.C.R. I-11613.
} 
residing in another Member State (D.I). Complementing this case, Grunkin and Paul demonstrates that EU citizens may benefit from the laws in the Member State of residence as well, also when those laws allow for personal statuses not existing in the Member State of nationality (D.II). ${ }^{29}$ By requiring other Member States to recognise the personal statuses obtained under the laws of another Member State, the ECJ is contributing to the federalisation of private international law in the European Union through the principle of mutual recognition (D.III). An examination of these cases and their consequences provide us with valuable lessons for the debate on the free movement of same-sex couples.

I. The importance of the nationalities of the Member States

Whereas EU citizenship is often accurately considered to belong to the federal citizenship family, ${ }^{30}$ the characteristic that distinguishes EU citizenship from citizenship in many contemporary federal states is the inversed relationship between EU citizenship and the citizenship of the Member States. ${ }^{31}$ Whereas state citizenship is commonly derived from federal citizenship, one only becomes an EU citizen upon the acquisition of the nationality of a Member State. The Treaty is very clear about this hierarchical relationship: "every person holding the nationality of a Member State [is] a citizen of the Union." ${ }^{32}$ Within the EU one is primarily a national of the Member State and only then an EU citizen. The nationality of a Union citizen, as a consequence, remains unaffected by a change in the Member State of residence. Rather uniquely, Union citizens might thus possess the (partial) membership of two Member States: the Member State of nationality and the Member State of residence by virtue of the right to non-discrimination. ${ }^{33}$ Vice-versa, the EU citizen who is residing in a Member State other than the one of her nationality is a full member of neither. That this hierarchical relationship is not without consequences has been demonstrated by Garcia Avello.

Esmeralda and Diego, the children of Mrs Weber and Mr Garcia Avello were born in Belgium, where they had resided all their live. They were in the possession of dual Spanish-Belgium nationality. The Belgian authorities had entered the children in the national registers under the surname Garcia Avello. Meanwhile, the children had been registered as Garcia Weber with the Spanish authorities. The father's request to change the surname, according to Spanish law, into Garcia Weber was rejected by the Belgian authorities. The question brought to the ECJ was whether this decision was contrary to the provisions on Union citizenship. ${ }^{34}$ The Court decided that a link with EU law exist for persons

\footnotetext{
${ }^{29}$ Case C-353/06 Grunkin and Paul [2008] E.C.R. I-7639.

${ }^{30}$ Christoph Schönberger, European Citizenship as Federal Citizenship: Some Citizenship Lessons of Comparative Federalism, 19 Revue Européenne de Droit Public 61 (2007).

${ }^{31}$ As Laycock observed, membership of an American State is not based on 'kinship'. Douglas Laycock, Equal Citizens of Equal and Territorial States: The Constitutional Foundations of Choice of Law, 92 Columbia Law Review 249 (1992). See also: Rainer Bauböck, The Three Levels of Citizenship within the European Union, 15 German Law Journal 751 (2014); Schönberger (note 30).

${ }^{32}$ Article 20 TFEU.

${ }^{33}$ The right to non-discrimination on the basis of nationality not only ensures that all Union citizens residing within the Member State receive equal treatment, but allows Union citizens coming from other Member State to become part and integrate in the host Member State. Loïc Azoulai, "Euro-Bonds" The Ruiz Zambrano Judgment or the Real Invention of EU Citizenship 3 Perspectives on Federalism 31 (2011).

${ }^{34}$ Garcia Avello (note 28) paras 13-19.
} 
"who are nationals of one Member State lawfully resident in the territory of another Member State". ${ }^{35}$ This being the case, the applicants could rely on the right to non-discrimination on grounds of nationality, enshrined in Article 18 TFEU. The Court, after coming to the conclusion that Belgian citizens who also possessed the Spanish nationality find themselves in a different position than those who are only in the possession of Belgian nationality, ${ }^{36}$ decided that "it is common ground that such a discrepancy in surnames is liable to cause serious inconveniences for those concerned at both professional and private levels". ${ }^{37}$ Belgium was placed under an obligation to recognise the Spanish surname of the couple.

It has been suggested that it was the applicants' dual nationality that was the relevant criterion in this case. ${ }^{38}$ Fortunately, however, the ECJ clarified in McCarthy that the possession of the double nationality alone is insufficient. ${ }^{39}$ The possession of a double nationality alone should not by itself bring the bearer of this dual status within the scope of EU law. The important and distinguishing characteristic of Garcia Avello is that Spain used nationality as a criterion to determine the applicability of its law on the spelling of names. As a consequence, "Belgian nationals who have divergent surnames by reason of the different laws to which they are attached by nationality may plead difficulties specific to their situation which distinguish them from persons holding only Belgian nationality, who are identified by one surname alone". ${ }^{40}$ It was not the dual nationality but the use of nationality, creating extraterritorial legal effects, ${ }^{41}$ which created the dilemma in Garcia Avello. In the absence of clear rules, the ECJ has provided Union citizens with the autonomy to decide the law applicable in case it can benefit from two or more different laws. ${ }^{42}$ The Member States are subsequently placed under the obligation to recognise this choice.

What Garcia Avello demonstrates is that the supremacy of the Member State's nationalities over EU citizenship matters. It must be evident also that the primacy of the nationalities of the Member States must matter. It was a very deliberate decision to grant EU citizenship to everyone in possession of a nationality of a Member State, not the other way around. The Treaty of Amsterdam unequivocally invigorated this intention: "Citizenship of the Union shall complement and not replace national citizenship". ${ }^{43}$ So, the well-known mantra of the ECJ that EU citizenship is "destined to be the

\footnotetext{
35 Id., para 27.

36 Id., paras 31-35.

37 Id., para 36.

${ }^{38}$ Matthias Lehman, What's in a Name? Grunkin-Paul and Beyond, 8 Yearbook of Private International Law 134,141 (2010); Cathryn Costello, Citizenship of the Union: Above Abuse?, in PROHIBITION OF ABUSE OF LAW: A NEW GENERAL PRINCIPLE OF EU LAW?, 331-332 (Rita de La Feria and Stefan Vogenauer eds., 2011).

${ }^{39}$ Case C-434/09 McCarthy v Secretary of State for the Home Department [2011] E.C.R. I-3375.

40 Garcia Avello (note 28) para 37.

${ }^{41}$ On the extraterritorial effects of the case law on personal statuses more generally see: Horatia Muir Watt, Future Directions?, in PRIVATE INTERNATIONAL LAW AND GLOBAL GOVERNANCE 343, 369-370 (Horatia Muir Watt and Diego P Fernández Arroyo eds., 2014).

42 On the party autonomy in the names cases see: Toni Marzal Yetano, The Constitutionalisation of Party Autonomy in European Family Law, 6 Journal of Private International Law 155 (2010); Jan-Jaap Kuipers, Cartesio and GrunkinPaul: Mutual Recognition as a Vested Rights Theory Based on Party Autonomy in Private Law, 2 European Journal of Legal Studies 66 (2009).

43 Now Article 20 TFEU.
} 
fundamental status of nationals of the Member States", ${ }^{44}$ thus, indeed seems "to be in tension with text, teleology and legislative history". "There is no "entirely conventional supremacy of Union citizenship;" " neither is it the case that "residence is the new nationality". ${ }^{47}$ By allowing EU citizens to benefit from the family law of their Member State of nationality, the ECJ can be said to have acknowledged the current legal status quo.

These findings must have consequences for the debate on the free movement of same-sex couples. If Spain is allowed to apply its family law on surnames to nationals living in another Member State, it seems hard to deny the Member States the possibility to apply its family law concerning marriages to nationals abroad. Some Member States have adopted legislation that allows them to do so. The Netherlands, for example, allows in addition to residents also nationals residing abroad to marry according to Dutch law. ${ }^{48}$ The Swedish law follows a very similar logic. ${ }^{49}$ Same-sex couples residing in Member States that preclude same-sex marriages may therefore get married according to Dutch or Swedish law if one of the partners is a Dutch or Swedish national. To return to our fictitious example from the introduction once more, would the Dutch-Polish same-sex couple decide to marry according to Dutch rules only after taking up residence in Greece, Greece would still be under the presumption to recognise this status. Garcia Avello, moreover, also raises serious questions about the decision of the German court, referred to in the introduction, which refused to recognise a same-sex marriage celebrated according to Dutch law of a Dutch national residing in Germany. If nationality may serve as an eligibility criterion in family law matters and if the EU citizen, in case of a conflict of laws, is given the autonomy to decide which law to benefit from, one must conclude that the German court should have been under the presumption to recognise the same-sex marriage.

II. Residence and non-discrimination on the basis of nationality

These conclusions do not suggest that nationals can only fall within the scope of the laws of their Member State of nationality. Grunkin and Paul, which complements Garcia Avello, demonstrates that EU citizens can also benefit from the laws of their Member State of residence, also when their Member State of nationality does not allow for the personal status as available in the Member State of residence.

The facts of that case concerned Leonhard Matthias, the son of $\mathrm{dr}$ Paul and mr Grunkin. Leonhard Matthias was born in Denmark but possesses German nationality, as do his parents. The

${ }^{44}$ Case C-184/99 Grzelczyk [2001] E.C.R. I-6193, para 31; Case C-413/99 Baumbast [2002] E.C.R. I-7091, para 82; Joined Cases C-482/01 and C-493/01 Orfanopoulos and Oliveri [2004] E.C.R. I-5257, para 65; Case C-34/09 Ruiz Zambrano [2011] E.C.R. I-1177, para 41.

$45 \mathrm{JHH}$ Weiler, Epilogue: Judging the Judges - Apology and Critique, in JUDGING EUROPE'S JUDGES: THE LEGITIMACY OF THE CASE LAW OF THE EUROPEAN COURT OF JUSTICE 235, 248 (Maurice Adams and others eds., 2013).

${ }^{46}$ Gareth Davies, The Entirely Conventional Supremacy of Union Citizenship and Rights, in HAS THE EUROPEAN COURT OF JUSTICE CHALLENGED MEMBER STATES SOVEREIGNTY IN NATIONALITY LAW (Jo Shaw ed., EUI RSCAS Working Paper 2011); Dimitry Kochenov, Case C-135/08, Janko Rottmann v. Freistaat Bayern, Judgment of the Court (Grand Chamber) of 2 March 2010, 47 Common Market Law Review 1831 (2010).

${ }^{47}$ For the opposite view see: Gareth Davies, “Any Place I Hang My Hat?" Or: Residence Is the New Nationality, 11 European Law Journal 43 (2005). For a critique of this view see: Floris de Witte, The End of EU Citizenship and the Means of Non-Discrimination, 18 Maastricht Journal of European \& Comparative Law 86, 102 (2011).

${ }^{48}$ Wet Conflictenrecht Huwelijk van 7 september 1989 (Trb. 1987, 137).

${ }^{49}$ Michael Bogdan, Private International Law Aspects of the Introduction of Same-Sex Marriages in Sweden, 78 Nordic Journal of International Law 253, 257 (2009). 
surname registered in Denmark was Grunkin-Paul. The parents requested the German authorities to register their son, who resides with his mother in Denmark, but often stays with his father in Germany, under the same surname. The authorities refused, insisting that since solely nationality was used as a connecting factor, only one of the surnames, Grunkin or Paul, could be accepted. ${ }^{50}$ This decision was challenged by the parents on the basis of the EU citizenship and non-discrimination provisions. ${ }^{51}$ Following earlier decisions, ${ }^{52}$ the Court affirmed that national legislation that disadvantages the Member State's nationals simply because they have availed themselves of the right to move and reside is a restriction of Article 21 TFEU. In other words, the Member State of nationality cannot treat their own nationals less favourably because they have during a certain period resided in another Member State and acquired rights there. Such is the case for someone "having to use a surname, in the Member State of which the person concerned is a national, that is different from that conferred and registered in the Member State of birth and residence". ${ }^{53}$ The justifications brought forward for using nationality as the sole connecting factor could not be accepted; this would undermine the continuity and stability of the personal status. ${ }^{54}$

Grunkin and Paul demonstrates that EU citizens are allowed to acquire a personal status on the basis of the laws of the Member State of residence, even if this status is not available in the Member State of nationality. Any other conclusion would have been problematic, of course, as that would have allowed for direct discrimination on the basis of nationality. ${ }^{55}$ Grunkin and Paul demonstrates, in addition, that in the case an EU citizen has the choice between two or more applicable laws it is given the autonomy to opt for the law of the Member State of residence. So, would the Garcia Avello family have preferred a surname formed according to Belgian rules, "they could have requested the Spanish authorities that their surname be changed to comply with Belgian law". ${ }^{56}$ Also this outcome is defensible, as it recognises the importance of the EU citizen's nationality as well as his place of residence. In the absence of legislation specifying with which Member State jurisdiction concerning marriage lies, the Court should acknowledge that both nationality as well as residence can serve as criteria by which the determine the applicability of the laws regulating personal status.

The relevance of these conclusions for the debate on the free movement of same-sex couples will be clear. If Member States allow residents to marry, EU citizens not possessing the nationality of that Member States should, on the basis of the right to non-discrimination on grounds of nationality, also be allowed to form such a partnership. The other Member States will be under the presumption to give recognition to this status. Member States cannot refuse to recognise the partnership of samesex couples legally acquired in another Member State on the basis of their private internal law only.

Residence is of course not always an entirely clear or undisputed criterion. Same-sex couples may decide to take up residence in another Member State for a brief period for the sole reason of entering into a marriage, after which they return to their Member State of origin. Member States

${ }^{50}$ Case C-353/06 Grunkin and Paul [2008] E.C.R. I-7639, paras 21-23 (Opinion of AG Sharpston).

${ }^{51}$ An earlier case, entailing the same facts, was dismissed by the ECJ: Case C-96/04 Niebüll [2006] E.C.R. I-3561.

${ }^{52}$ Case C-406/04 De Cuyper [2006] E.C.R. I-6947, para 39; Case C-499/06 Nerkowska [2008] E.C.R. I-3993, para 32.

53 Grunkin and Paul (note 29) paras 21-22.

54 Id., paras 30-32.

55 Kochenov (note 25) 199.

${ }^{56}$ Marzal Yetano (note 42) 159; Meeusen (note 5) 296. 
confronted with EU citizens taking up residence in another Member State for the mere purpose of evading the less hospitable regime at home may claim this to be an instance of abuse of EU law. ${ }^{57} \mathrm{We}$ should be hesitant about accepting such claims and ought to be careful not to confuse circumvention of national laws with abusive practices. ${ }^{58}$ For there to be an abuse of free movement law, not only must the exercise of the right to free movement be artificial, that is, the obtainment of the gain should be the sole reason for moving, ${ }^{59}$ but also should it be contrary to the objectives of those legal rules. ${ }^{60}$ It is due to the latter's teleological reasoning that the Court found artificial practices for the purpose of tax avoidance an abuse of law, but not decisions to incorporate companies in the most beneficial legal regime. ${ }^{61}$ Whereas tax avoidance is contrary to the objectives of the free movement rules, ${ }^{62}$ the right to form a company "in the Member State whose rules of company law seem to him the least restrictive and to set up branches in other Member States (...) is inherent in the exercise, in a single market, of the freedom of establishment guaranteed by the Treaty". ${ }^{63}$ Considering that the free movement rights' purpose is to provide opportunities to EU citizens, allowing them to "vote with their feet" and choose the legal regime that is most beneficial for them, ${ }^{64}$ it cannot be of itself an abuse of the right to free movement for an EU citizen to choose the legal regime with the most beneficial marital rules.

It is not unimaginable though that the connection with a Member State is entirely tenuous. The above situations leave unanswered the question if Member States also are under a presumption of recognition in case same-sex couples have celebrated a same-sex marriage in a Member State in which they were not residing and neither possessed the nationality. Considering that most Member States seem to have included nationality or residence requirements in their laws regulating marriage, this situation does not seem to be too likely to happen. Would it occur though, non-recognition is easiest to justify in these situations, at least if we accept, as done throughout this article, that Member States have a right to govern their own residents and/or nationals. ${ }^{65} \mathrm{EU}$ law should have sufficient tools to deal with connections to a Member State that truly prove to be too tenuous. While nationality

\footnotetext{
${ }^{57}$ On the concept of abuse of law see: ALEXANDRE SAYDÉ, ABUSE OF EU LAW AND REGULATION OF THE INTERNAL MARKET (2014); RITA DE LA FERIA AND STEFAN VOGENAUER (EDS), PROHIBITION OF ABUSE OF LAW: A NEW GENERAL PRINCIPLE OF EU LAW? (2011).

${ }^{58}$ Luca Cerioni, The "Abuse of Rights" in EU Company Law and EU Tax Law: A Re-Reading of the ECJ Case Law and the Quest for a Unitary Notion, 21 European Business Law Review 783, 789 (2010).

${ }^{59}$ Case C-255/02 Halifax [2006] E.C.R. I-1609, para 69; Case C-110/99 Emsland-Stärke [2000] E.C.R. I-11569, para 51. See also: Saydé (note 57) 83-93.

${ }^{60}$ Case C-212/97 Centros [1999] E.C.R. I-1459, para 25.

${ }^{61}$ Pierre Schammo, Arbitrage and Abuse of Rights in the EC Legal System, 14 European law journal 351 (2008); Saydé (note 57) 93-98.

62 Case C-196/04 Cadbury Schweppes [2006] E.C.R. I-7995, paras 54-64.

${ }^{63}$ Case C-212/97 Centros [1999] E.C.R. I-1459, para 27; Case C-167/01 Inspire Art [2003] E.C.R. I-10155, paras 137138.

${ }^{64}$ On voting with one's feet see: Kreimer (note 25); Richard A Epstein, Exit Rights Under Federalism, 55 Law and Contemporary Problems 147 (1992). For a more sceptical view see: Douglas Laycock, Voting with Your Feet Is No Substitute for Constitutional Rights, 32 Harvard Journal of Law \& Public Policy 29 (2009). For a translation of these ideas in the context of the EU see: Floris de Witte, Transnational Solidarity and the Mediation of Conflicts of Justice in Europe, 18 European Law Journal 694, 699 (2012); Kochenov (note 25).

${ }^{65}$ See also: Koppelman (note 11) 102.
} 
might very well be considered as providing a sufficiently strong connection with a Member State in any case, ${ }^{66}$ a distinction between residence and a mere visit can be made on the basis of a habitual residence test, as present in some of the EU's private international law legislation, ${ }^{67}$ or by examining whether the residence is "genuine", as done by the ECJ in more recent family reunification case law. ${ }^{68}$ This should provide for sufficient safeguards against circumventions of national law through abusive u-turns.

In general, however, Member States should be under the presumption to recognise marriages celebrated in other Member States, also if it concerns their nationals who have been resident in the Member State of marriage only for a brief period of time.

III. The federalisation of private international law in the Europe Union through the principle of mutual recognition

From the above it follows that, unless legitimate justifications can be brought forward, ${ }^{69}$ Member States are required to recognise the personal status acquired according to the laws of other Member States. This development falls nothing short of a federalisation of private international law within the EU through the application of the principle of mutual recognition.

This development, through the rather orthodox application of this principle, will probably not surprise EU lawyers. ${ }^{70}$ Private international lawyers, on the other hand, have been more amazed by these developments. For long, the effect of EU law on private international law has been underestimated, which is undoubtedly also due to indications given by the ECJ that national private internal law provisions fell outside the scope of the Treaty. ${ }^{71}$ Grunkin and Paul leaves no doubt that this is no longer the case. Contrary to what was argued by Germany in Grunking and Paul, ${ }^{72}$ it was not allowed to subject Union citizens coming from other Member States to their private international laws.

It has been suggested that, due to the lack of clear country of origin in Garcia Avello and Grunkin and Paul, these cases cannot be explained with reference to mutual recognition. ${ }^{73}$ The principle of mutual recognition, however, has long been recognised as comprising more than a country of origin rule; it can also be invoked against the home Member State. ${ }^{74}$ In addition, functional equivalence is no prerequisite for the application of the principle of mutual recognition: ${ }^{75}$ also "in the absence (...) even

\footnotetext{
${ }^{66}$ Case C-168/08 Haddadi [2009] E.C.R. I-6871.

${ }^{67}$ Council Regulation (EC) No 2201/2003 of 27 November 2003 concerning jurisdiction and the recognition and enforcement of judgments in matrimonial matters and the matters of parental responsibility (OJ L338 0001-0029).

${ }^{68}$ Case C-456/12 O and B [2014] nyr.

${ }^{69}$ On justifying non-recognition see: CHRISTINE JANSSENS, THE PRINCIPLE OF MUTUAL RECOGNITION IN EU LAW (2013) chapter 1.

70 Vonk (note 42) 148; Janssens (note 69) footnote 46.

71 In 1999, the ECJ still maintained that the national provisions of private international law determining the substantive national law applicable to the effects of a divorce [do not] fall within the scope of the Treaty. Case C430/97 Johannes [1999] E.C.R. I-3475, para 27.

72 Grunkin and Paul (note 26) paras 32-34.

${ }^{73}$ Kuipers (note 42) 83-84.

${ }^{74}$ For an analysis see: Janssens (note 69) 38-40.

${ }^{75}$ See again: id., 30-38.
} 
of a system of equivalence, restrictions on the freedom guaranteed by the Treaty (...) may arise". ${ }^{76}$ To what extent mutual recognition is appropriate in the absence of some sense of common principles is indeed a very valid question, ${ }^{77}$ but that the laws on the spelling on surnames are not equivalent in the different Member States should not deter us from describing the situation in Garcia Avello and Grunkin and Paul as one of mutual recognition.

Initial signals from the ECJ aside, also private international lawyers cannot be entirely surprised about the reach of EU law. The decision to apply the principle of mutual recognition, thereby moving beyond national private international law, is entirely logical. The need to protect the exercise of the right to move and reside has already given rise to the adoption of EU legislation in the field of private international law. It cannot surprise, therefore, that also the ECJ gives preference to the right to free movement when it is undermined by the application of a Member State's private international legal rules. ${ }^{78}$ What we are witnessing, in fact, is a "federalisation" of private international law. Federal unions that aim to guarantee and facilitate the free movement of persons among the constituent states will need to ensure that the effects of movement on the personal statuses of their citizens are, as far as possible, neutral. Demands for legal certainty and justice in federal unions that have not unified the substantive law are likely to result in the development of an "interstate private law". ${ }^{79}$ Respect for those principles is even more important in an area of freedom, security, and justice. ${ }^{80}$ To avoid restrictions to free movement, there is thus a need for principles or rules to be adopted at the federal level. Those rules may take different forms, ranging from mere principles to harmonised rules ${ }^{81}$ and allowing for more or less freedom for the constituent states. The move away from conventional international private law seems to be inevitable though in a union that purports to ensure the free movement of citizens throughout the federal territorial space. ${ }^{82}$

${ }^{76}$ Case C-288/89 Stichting Collectieve Antennevoorziening Gouda [1991] E.C.R. I-4007, para 12; Case C-353/89 Commission $v$ the Netherlands [1991] E.C.R. I-4069, para 16.

77 Meeusen (note 5) 303.

${ }^{78}$ Johan Meeusen, The Grunkin and Paul Judgment of the ECJ, or How to Strike a Delicate Balance between Conflict of Laws, Union Citizenship and Freedom of Movement in the EC, 18 Zeitschrift für Europäisches Privatrecht 186 (2010); Gerard-Rene de Groot, Towards European Conflict Rules in Matters of Personal Status, 11 Maastricht Journal of European \& Comparative Law 115 (2004).

${ }^{79}$ Vanessa Abballe, Comparative Perspectives of the Articulation of Horizontal Interjurisdictional Relations in the United States and the European Union: The Federalization of Civil Justice, 15 New England Journal of International \& Comparative Law 1 (2009); Alex Mills, Federalism in the European Union and the United States: Subsidiarity, Private Law, and the Conflict of Laws, 32 University of Pennsylvania Journal of International Law 369 (2010); Milena Sterio, The Globalization Era and the Conflict of Laws: What Europe Could Learn from the United States and Vice Versa, 13 Cardozo Journal of International and Comparative Law 161 (2005); Michaels (note 9); Alex Mills, Variable Geometry, Peer Governance, and the Public International Perspective on Private International Law, in PRIVATE INTERNATIONAL LAW AND GLOBAL GOVERNANCE (Horatia Muir Watt and Diego P Fernández Arroyo eds., 2014); Jacco Bomhoff, The Constitution of the Conflict of Laws, in PRIVATE INTERNATIONAL LAW AND GLOBAL GOVERNANCE (Horatia Muir Watt and Diego P Fernández Arroyo eds., 2014).

${ }^{80}$ For the importance of EU conflict of law rules in an area of freedom, security, and justice, see: Meeusen (note 5).

${ }^{81}$ The EU has, interestingly, opted for a much more centralised approach than the US. See: Abballe (note 79).

${ }^{82}$ Also in the US, interstate jurisdictional conflicts were initially governed by more traditional international private law. Harold L Korn, The Development of Judicial Jurisdiction in the United States: Part 1, 65 Brooklyn Law Review 935, 969-970 (1999). 
The principle of mutual recognition requires Member States to recognise rights acquired in another Member State and to refrain from imposing additional obstacles. In the case of surnames, Member States are thus under an obligation, absent justifiable overriding requirements, to recognise the name acquired lawfully in another Member State. There appears to be no reason why this logic should be different for other personal statuses. The development of a federal private law within the EU, through the principle of mutual recognition, consequently, presumes that Member States recognise same-sex marriages legally celebrated in another Member State. The Member States that have so far not opened up marriage to same-sex couples cannot invoke their private international law to justify the non-recognition of the marriage.

In addition, the cases tell us that the principle of mutual recognition can also be invoked against the Member State of origin, or perhaps it is more accurate to say that the Member State of origin is not necessarily the Member State of nationality. Germany, the Member State of nationality of the entire Grunkin and Paul family, had to recognise the surname required according to Danish law. For the debate on the free movement of same-sex couples this implies that Member States that do not allow same-sex couples to marry cannot by definition declare void the marital status obtained by their nationals in another Member State. Also this cannot surprise, of course. After all, it is anything but a new development that the free movement provisions can be invoked against the Member State of nationality. ${ }^{83}$

\section{E. National and constitutional identities matter}

Those having followed the development of the case law on the recognition of names might not be too astounded by this analysis and the lessons derived from those cases. Those in support of the mutual recognition of same-sex marriages have in fact also used those cases to support their claims. Another, contrasting lesson needs to be distilled from the name cases though; one which stands in stark contrast with what has been discussed so far. Whereas a policy of automatic non-recognition of same-sex marriages legally celebrated in another Member State clearly ignores some of the requirements imposed upon the Member States by EU law, also those who have argued in favour of unconditional mutual recognition have ignored essential aspects of the name cases. Most importantly, and following most clearly from Sayn-Wittgenstein and Runevič-Vardyn, the national and constitutional identities of the Member States matter.

The applicant in Sayn-Wittgenstein, an Austrian citizen born in 1944, was adopted in 1991 by Mr Lothar Fürst von Sayn-Wittgenstein. The applicant was living in Germany at the time of the adoption and continued to live there pending the decision. Due to the adoption, the applicant acquired the surname of her father in the form 'Fürstin von Sayn-Wittgenstein'. The Austrian authorities registered that name in the Austrian register and issued several documents in the name of Ilonka Fürstin von Sayn-Wittgenstein. In 2003, however, the Austrian Constitutional Court interpreted the Austrian law on the abolition of the nobility as precluding an Austrian citizen from acquiring a surname bearing titles of nobility. Following this decision, the Austrian authorities adopted the view that the birth certificate issued was incorrect and sent the applicant a letter informing her that the

\footnotetext{
${ }^{83}$ See, for example: Case C-224/98 D'Hoop [2002] E.C.R. I-6191.
} 
surname would be changed to Sayn-Wittgenstein. The applicant challenged this decision on the basis of the free movement provisions in EU law. ${ }^{84}$

In line with the cases discussed above, the ECJ again held it to be an obstacle to the right to move and reside to oblige a Union citizen "to use a surname, in the Member State of which he is a national, which is different from that already conferred and registered in the Member State of birth and residence". ${ }^{85}$ Partially because the Austrian authorities for many years recognised the name and issued documents bearing this name, the sudden non-recognition would result in serious inconveniences for the applicant. This justified the conclusion that there exists a restriction to the right to move and reside. ${ }^{86}$ The justifications brought forward by the Austrian government, however, which claimed that the law on the abolition of the nobility enjoys constitutional status and implements the principle of equal treatment, ${ }^{87}$ were swiftly accepted. Considering, firstly, that the protection of the principle of equality is compatible with EU law and, secondly, that the EU is according to Article 4(2) TEU under a duty to respect the national identities of the Member States, the obstruction to the right to free movement was held to be legitimate. ${ }^{88}$

The argumentation employed in Runevič-Vardyn was alike. Ms Runevič-Vardyn is a Lithuanian national belonging to the Polish minority in Lithuania. Her parents gave her the first name 'Małgorzata' and the surname 'Runiewicz'. The birth certificate issued in 1977 spelled the applicant's name using Cyrillic characters. A newly issued birth certificate in 2003, using the Roman alphabet, spelled the names according to the Lithuanian form as 'Malgožata Runevič'. The Polish authorities issued the applicant a birth certificate in 2006, which spelled the name according to Polish rules as 'Małgorzata Runiewicz'. Also the marriage certificate used Polish spelling rules. After having lived in Poland for some time, the applicant married Lukasz Paweł Wardyn, the second applicant. On the marriage certificate issued by the Lithuanian authorities, the name of the second applicant is transcribed as 'Lukasz Pawel Wardyn' and the first applicant's name as 'Malgožata Runevič-Vardyn'. The first applicant requested that the Lithuanian authorities change her names to 'Małgorzata Runiewicz', on the birth certificate, and 'Małgorzata Runiewicz-Wardyn', on the marriage certificate. The Lithuanian authorities refused to do so, arguing that such would be against the national rules. ${ }^{89}$

Only with respect to the second complaint, that the husband's surname be added to the maiden name in a form that "does not correspond to the husband's surname as registered in the Member State of origin", ${ }^{90}$ it was decided that such treatment is precluded if "there is a real risk (...) that family members will be obliged to dispel doubts as to their identity and the authenticity of the documents which they submit". ${ }^{11}$ The other two complaints were dismissed for not violating the right to non-discrimination and free movement. With respect to the second complaint, however, the Court agreed with the justifications brought forward by Lithuania, which submitted that the national

\footnotetext{
${ }^{84}$ Case C-208/09 Sayn-Wittgenstein [2010] E.C.R. I-13693, paras 19-29.

85 Id., para 54.

${ }^{86}$ Id., paras 62-71.

87 Id., para 32.

88 Id., paras 88-95.

${ }^{89}$ Case C-391/09 Runevič-Vardyn [2011] E.C.R. I-3787, paras 15-27.

90 Id., para 74.

91 Id., para 77.
} 
measures were justified by the need to protect the cultural, constitutional, and national identity of Lithuania. The ECJ concluded that the EU is under a duty to "respect its rich cultural and linguistic diversity". ${ }^{2}$ Article 4(2) TEU, in addition, requires the respect for "the national identity of its Member States, which includes protection of a State's official national language". ${ }^{33}$ Lithuania had to strike a balance with the right to a personal identity and private life though, which was for the national court to do. ${ }^{94}$

These two cases first of all lend further support to the conclusion adopted on the basis of Grunkin and PauPs analysis: the refusal to recognize a personal status granted legally in another Member State is considered to be an obstacle to the right to free movement, which must be objectively justifiable in order not to be found in violation of EU law. In addition, Sayn-Wittgenstein and RunevičVardyn demonstrate the ECJ's willingness to consider and accept the justifications brought forward by the Member States.

By referring and giving substance to Article 4(2) TEU for the first time, the Court clarified that the national identities of the Member States matter. That the Court takes into account such concerns is not unique. ${ }^{95}$ In Groener, decide din the 1980 s, which concerned a Dutch national who was not allowed to obtain a permanent full-time lecturer position in Ireland due to her inadequate knowledge of the Irish language, the ECJ held that the Treaty allows policies protecting national languages. Even though knowledge of the Irish language was not required for the lectureship, the fact that the Irish constitution recognises the Irish language as the first official language justified the requirement. ${ }^{96}$ In Omega, moreover, the ECJ allowed Germany to invoke the constitutional value of human dignity as a justification for a ban on laser games simulating homicide. ${ }^{97}$

It seems hard to dispute, "if it is more than a noble gesture", ${ }^{98}$ that the identity clause in Article 4(2) ought to be capable of justifying deviations from EU law. The clause does not merely reflect that a common identity is largely absent within the EU and that the constitutions of the Member States may rest upon different normative foundations, it also requires that those differences must "be respected rather than overcome". ${ }^{99}$ In the face of such diverging values, it is important to give due regard to the differences; not allowing for flexibility in the case of diversity may very well undermine the basis of the Union's legitimacy. ${ }^{100}$

\footnotetext{
92 Id., para 86.

${ }^{93}$ Id.

94 Id., paras 89-91.

${ }^{95}$ For an overview of references to national identity in the case law of the ECJ as well as AG Opinions see: Laurence Burgorgue-Larsen, A Huron at the Kirchberg Plateau or a Few Naïve Thoughts on Constitutional Identity in the CaseLaw of the Judges of the European Union, in NATIONAL CONSTITUTIONAL IDENTITY AND EUROPEAN INTEGRATION 275 (Alejandro Saiz Arnaiz and Carina Alcoberro Llivina eds., 2013).

${ }^{96}$ Case C-379/87 Groener [1989] E.C.R. 3967, paras 15-20.

${ }_{97}$ Case C-36/02 Omega [2004] E.C.R. I-9609.

${ }^{98}$ ALEXANDER SOMEK, INDIVIDUALISM: AN ESSAY ON THE AUTHORITY OF THE EUROPEAN UNION (2008) 94.

${ }^{99}$ Leonard FM Besselink, National and Constitutional Identity before and after Lisbon, 6 Utrecht Law Review 36, 41 (2010).

${ }^{100}$ Fritz Scharpf, Legitimate Diversity: The New Challenge of European Integration, in THE STATE OF THE EUROPEAN UNION: LAW, POLITICS, AND SOCIETY 79 (Tanja A Börzel and Rachel A Cichowski eds., 2003).
} 
The identity clause should not, of course, allow Member States to determine unilaterally when to derogate from EU law. ${ }^{101}$ After all, the "respect owed to the constitutional identity of the Member States cannot be understood as an absolute obligation to defer to all national constitutional rules." 102 "Instead, it imposes the obligation on the Union to provide, in certain cases, for the exception to the uniform application of EU law." ${ }^{103}$ It is in the end up to the ECJ to decide whether it accepts the identity claims made by the Member States, as it has done in pre-Lisbon case law as well. ${ }^{104}$ Nevertheless, it would be wise would the Court proceed with care when scrutinising national identity claims. The ECJ does not appear to be in the position from which to decide which aspects belong to the national and constitutional identities of the Member States. ${ }^{105}$

Evidently, the growing relevance of the identity clause poses serious challenges for those who consider the principle of mutual recognition to be a means to safeguard the free movement of samesex couples. Of course, the principle of mutual recognition has never been unconditional. ${ }^{106}$ The argument that the ECJ is the right actor to settle issues concerning the recognition of same-sex couples' legal statuses because its economic analysis "does not involve deference to the national concerns of the Member States" ${ }^{107}$ thus simply ignores long lines of case law. Taking the national and constitutional identities of the Member States in due consideration creates additional difficulties, however, precisely because the diverging normative positions on same-sex marriage go to the core of how Member States define themselves. That a number of Member States have adopted constitutional provisions clarifying that marriage can only be a union between men and women reflects this very well. It seems hard to deny, therefore, that those Member States can "invoke [their] constitutional understanding of the institution of marriage" when defending the obstruction to the right to free movement. ${ }^{108}$

Confronted with the observation that Member States may justify their policies, the response has very often been rather predictable, dismissing the idea that Member States can possibly justify the non-recognition of a same-sex marriage by a reference to fundamental rights. ${ }^{109} \mathrm{It}$ is not disputed here that the fundamental rights dimension is entirely relevant and, as such, requires our careful attention. This fundamental rights argument, however, presents us with several dilemmas. First, after SaynWittgenstein and Runevic-Vardyn ${ }_{2}$ such an argument cannot be made any longer without a fierce critique of those cases. The fundamental rights dimension of the free movement of same-sex couples is evident,

\footnotetext{
${ }^{101}$ Case C-393/10 O'Brien [2012] nyr, para 49.

102 Case C-213/07 Michaniki [2008] E.C.R. I-9999, para 33 (Opinion of AG Maduro).

103 Monica Claes, National Identity: Trump Card or Up for Negotiation?, in NATIONAL CONSTITUTIONAL IDENTITY AND EUROPEAN INTEGRATION (Alejandro Saiz Arnaiz and Carina Alcoberro Llivina eds., 2013). See also: Armin Von Bogdandy and Stephan Schill, Overcoming Absolute Primacy: Respect for National Identity under the Lisbon Treaty, 48 Common Market Law Review 1417 (2011).

${ }^{104}$ Case C-473/93 Commission v Luxembourg [1996] E.C.R. I-3207, para 32-36.

105 ELKE CLOOTS, NATIONAL IDENTITY IN EU LAW 12-13 (2015); Elke Cloots, Case C-202/11, Anton Las v. Psa Antwerp NV, Judgment of the Court of Justice (Grand Chamber) of 16 April 2013, 51 Common Market Law Review 623,641 (2014).

106 Janssens (note 69) 13.

107 Andrew Stumer, Homosexual Rights and the Free Movement of Persons in the European Union, 7 International Trade \& Business Law Annual 205, 221 (2002).

108 Cloots (note 89) 285-286.

${ }^{109}$ Bonini Baraldi (note 21); Ertuna Lagrand (note 20); Tryfonidou (note 17).
} 
but also the name cases are not free from fundamental rights concerns. ${ }^{110}$ The Lithuanian legislation at stake in Runevič-Vardyn has been criticised for not respecting minority rights. ${ }^{111}$ Nonetheless, the justifications brought forward by Lithuania were accepted by the Court. It merely ordered the national court to take into account the right to private and family life when considering whether the Lithuanian authorities had struck the right balance. ${ }^{112}$ The idea that Member States may rely on Article 4(2) TEU only as long as it respects the fundamental values upon which the EU is founded, laid down in Article 2 TEU, is, as a consequence, doubtful. ${ }^{113}$ To argue that the fundamental rights must trump national identity concerns is contrary to what was decided in Sayn-Wittgenstein and Runevic-Vardyn.

Of course, one may criticise these cases and argue that the application of the national identity clause should never result in a restriction of fundamental rights. Considering the use of fundamental rights in the debate on free movement of same-sex couples, it is somewhat surprising, that the fundamental rights dimension of Runevic-Vardyn has received scant attention. ${ }^{114}$ Considering the minority rights at stake in that case, the rather deferential proportionality analysis is rather surprising, to say the least. ${ }^{115}$ The idea that fundamental rights by definition trump the national identity clause is one that must be dismissed, however, for three reasons. The first two demonstrate that such an idea is far from feasible. As Sayn-Wittgenstein demonstrates, first of all, the Court may be confronted with a clash between different fundamental rights; in that case, a conflict between the principle of equal treatment and the right to private life. ${ }^{116}$ This alone demonstrates why the Court cannot always side with the fundamental rights at stake. ${ }^{117}$ In addition, it is difficult to define what qualifies as a fundamental right and how broad they must be construed. A fundamental rights as trump argument

${ }^{110}$ Case C-168/91 Konstantinidis [1993] E.C.R. I-1191, para 40 (Opinion of AG Jacobs); Case C-391/09 Runevič-Vardyn [2011] E.C.R. I-3787, para 89; Matthew J Elsmore and Peter Starup, Union Citizenship - Background, Jurisprudence, and Perspective: The Past, Present, and Future of Law and Policy, 26 Yearbook of European Law 57, 91-92 (2007).

111 GAETANO PENTASSUGLIA, MINORITY GROUPS AND JUDICIAL DISCOURSE IN INTERNATIONAL LAW: A COMPARATIVE PERSPECTIVE, 67-68 (2009). Generally the new Member States are unlikely to do more than the minimum to protect their minorities: Will Kymlicka, National Minorities in Postcommunist Europe: The Role of International Norms and European Integration, in ETHNIC POLITICS AFTER COMMUNISM (Zoltan Barany and Robert G Moser eds., 2005).

112 Runevič-Vardyn (note 84) Para 91.

113 For such a claim see: Von Bogdandy and Schill (note 103) 1430.

114 The main analysis so far hardly considers the fundamental rights dimension: Hanneke van Eijken, Case note on C391/09 Runevič-Vardyn, 49 Common Market Law Review 809 (2012). But see, very recently, Olivier Dubos and Victor Guset, European Law and Regional or Minority Languages: Cultural Diversity and the Fight against Linguistic Vulnerability, PROTECTING VULNERABLE GROUPS: THE EUROPEAN HUMAN RIGHTS FRAMEWORK (Francesca Ippolito and Sara Iglesias Sanchez eds., 2015).

115 Whereas the ECJ held in in Garcia Avello that the national measures were disproportionate because Belgium had already allowed 'derogations from application of the Belgian system of handing down surnames in situations similar to that of the children of the applicant in the main proceedings' (para 44), the Lithuanian refusal to rewrite Vardyn as Wardyn was only possibly disproportionate, which was ultimately for the national court to decide, even though Lithuanian authorities normally allowed for the use of the letter W (paras 92-93). For the inconsistent application of the proportionality test in relation to the national identity clause see also: Cloots (note 89).

${ }^{116}$ Even though the case did not contain an explicit reference to the right to private life, all name cases raise this issue (see, supra, note 110).

${ }^{117}$ For a powerful analysis see: Joseph HH Weiler, Fundamental Rights and Fundamental Boundaries: On Standards and Values in the Protection of Human Rights, in THE EUROPEAN UNION AND HUMAN RIGHTS (Nanette A Neuwahl and Alan Rosas eds., 1995). 
combined with a broad definition will basically render the identity clause meaningless. Those critical of the national identity clause, who see it as a threat to the unity of the European legal order, might be happy with such an outcome. A different position is taken here, because there must be legitimate scope for diversity, disagreement and contestation in a pluralist legal order. ${ }^{118}$

From this follows the third and most fundamental problem concerning the belief that the national identity clause cannot be invoked if this result in a restriction of a fundamental right. Fundamental rights are, due to their universal premises, likely to function as centripetal forces within a polity. Their legal codification is likely only to increase the centralising propensity of fundamental rights. The inevitable tensions such dynamics may create in pluralist societies is, ${ }^{119}$ as shown by this section, also present within the EU. An approach that focuses on rights only, or which ignores that there can be legitimate disagreement about the interpretation of a right, ${ }^{120}$ is likely to ignore or downplay those tensions, as well as the mechanisms that countervail such centralising tendencies that may have been adopted. ${ }^{121}$ One of those countervailing mechanisms within the EU, of course, is the national identity clause. The most fundamental objection to an approach that focuses on rights only is thus that it overlooks that the EU has promised to promote and respect a range of values and objectives, of which the respect for fundamental rights is a very important one. The respect for the national and constitutional identities of the Member States, however, belongs to those as well. Instead of considering fundamental rights as (quasi-)automatic trumps over the identity clause, a more balanced approach, which recognises the tensions and allows for mediation between the conflicting values, seems warranted.

\section{F. A federal clash of values and some possible solutions}

Rather than adopting a hierarchical vision, whereby everything is subordinated to fundamental rights, Article 4 TEU must be regarded as the Union's federal provision, which recognises the reciprocal relationship between the EU and the Member States and requires mutual respect. ${ }^{122}$ To that aim, Article 4 TEU encloses, in addition to the requirement of respect for the national identity of the Member States, the principle of limited conferral of competences (Art. 4(1) TEU), the equality of the Member States (Art 4(2) TEU) and the respect for the Member States' essential State functions (Art 4(2) TEU). Article 4(3) TEU, in addition, provides for the "“"glue" to keep the federal construction together", ${ }^{123}$ namely the principle of sincere cooperation. Accordingly, Member States must adopt the necessary measures "to ensure fulfilment of the obligations arising out of the Treaties" as well as "refrain from any measure which could jeopardise the attainment of the Union's objectives".

\footnotetext{
${ }^{118}$ With pluralism I refer to value pluralism, not to legal pluralism. On the difference between the two see: Michel Rosenfeld, Constitutional Versus Administrative Ordering in an Era of Globalization and Privatization: Reflections on Sources of Legitimation in the Post-Westphalian Polity, 32 Cardozo Law Review 2339, 2340 (2010).

${ }^{119}$ Richard Bellamy, Constitutive Citizenship versus Constitutional Rights: Republican Reflections on the EU Charter and the Human Rights Act, in SCEPTICAL ESSAYS ON HUMAN RIGHTS 31 (Tom Campbell, Keith Ewing and Adam Tomkins eds., 2001).

120 JEREMY WALDRON, LAW AND DISAGREEMENT (1999) 12.

${ }^{121}$ Bellamy (note 119).

122 Von Bogdandy and Schill (note 87) 1425.

${ }^{123}$ ELKE CLOOTS, GEERT DE BAERE, AND STEFAN SOTTIAUX (EDS), FEDERALISM IN THE EUROPEAN UNION viii (2012).
} 
The latter principle, which is analogous to the "fidelity principle" that governs relations within federal states, ${ }^{124}$ gives further support to the conclusions in the first two sections: The Member States are no longer completely foreign to each other; the Treaties provide for an overarching set of norms which justify the disapplication of the private international law rules, ${ }^{125}$ which Member States may still invoke against non-Member States. The dark side of the fidelity principle, however, is that it may suppress diversity rather than that it generates "vibrant democratic interaction by a greater number of constituencies and elected politicians regarding the needs of the political system as a whole". ${ }^{126}$ From the perspective of self-determination, strong support can be derived for respecting the moral and value choices of the Member States, even if they run counter to what we find normatively acceptable. ${ }^{127}$ The other provisions in Article 4 TEU aspire to leave room for such a debate, particularly when the matters at stake are delicate. Too often it is ignored, so appears to me, that the definition and delineation of fundamental rights may belong to those matters; differences in fundamental rights protection within Member States, after all, "reflect fundamental societal choices and form an important part in the different identities of polities and societies". ${ }^{228}$

It should be evident that the above argument does not suggest that the national identity clause by definition allows Member States not to recognise same-sex marriages legally celebrated in another Member State. The Union's legitimacy, after all, also derives from the fact that it is capable to treat the other as one of us, despite the differences: "despite the boundaries which are maintained, and constitute the I and the Alien, one is commanded to reach over the boundary and accept him". ${ }^{129}$ This, however, should not prevent us from discussing the limits of mutual recognition. To agree with Nicolaïdis, we must ask to what extent "recognition between states' laws and regulations create resistance to recognition between peoples". ${ }^{130}$

The ostensible incommensurability of those conflicting legal norms presents the EU with a great dilemma. Rather than unilaterally imposing 'European' standards upon the Member States, or placing the issue outside the free movement legal framework altogether, we must seek for an approach that balances those conflicting interests. We need a framework of analysis that should provide insights as to when the protection of a Member State's national identity provides for a legitimate obstacle to the right to free movement. ${ }^{131}$

Despite its gravity, the dilemma is not irresolvable. That people can and will disagree over which morals are good or bad, right or wrong, should not allow them to disrespect the intrinsic worth of human beings. Entirely bigoted interests should, therefore, not be accepted. In addition, the range of interests Member States can invoke has also been limited by the case law of the ECtHR. Regulating

\footnotetext{
124 DAMIAN CHALMERS, GARETH DAVIES, AND GIORGIO MONTI, EUROPEAN UNION LAW (2014) 213.

${ }^{125}$ For this conclusion see also: Michaels (note 45) 235.

${ }^{126}$ Daniel Halberstam, Of Power and Responsibility: The Political Morality of Federal Systems 90 Virginia Law Review 731, 737 (2004).

${ }^{127}$ Floris de Witte, Sex, Drugs \& EU Law: The Recognition of Moral and Ethical Diversity in EU Law, 50 Common Market Law Review 1545, 1546-1551 (2013).

128 Weiler (note 103) 51.

129 Joseph HH Weiler, In defence of the status-quo: Europe's constitutional Sonderweg, in EUROPEAN CONSTITUTIONALISM BEYOND THE STATE 7, 20 (JHH Weiler and Marlene Wind eds., 2003).

130 Kalypso Nicolaïdis, European Demoicracy and Its Crisis, 51 Journal of Common Market Studies 351, 360 (2013).

${ }^{131}$ For an interesting approach see: Cloots (note 89).
} 
the sexual conduct of same-sex couples or expressing moral disapproval of same-sex relations through legislation is no longer allowed within the Council of Europe Member States and, hence, within the EU. ${ }^{132}$ Criminalising homosexual conduct has been found to be in breach of the Convention and, ${ }^{133}$ in more recent years, the ECtHR has also taken a strong stance against expressing moral disapproval or discouraging homosexual conduct by singling out same-sex couples and subjecting them to discriminatory treatment. ${ }^{134}$ This notion found its clearest expression in Vallianatos and Others v Greece, where the ECtHR decided that Greece had breached the Convention by excluding same-sex couples from civil unions. ${ }^{135}$

The ECtHR case law may not get us very far, however, if a Member State "invoke[s] its constitutional understanding of the institution of marriage, but not the conviction that homosexuality is incompatible with its national identity". ${ }^{136}$ Member States might believe that marriage is essentially heterosexual, either due to its link to procreation or for other reasons, and still design policies which respect and protect the human dignity of same-sex persons. ${ }^{137}$ This is also precisely what the case law of the ECtHR seems to allow. While the contracting states may protect the "family in the traditional sense", ${ }^{138}$ rights granted to non-married persons should be granted to heterosexuals and homosexuals alike. It will, for this reason, not be always possible to escape a balancing of the different interests at stake.

How to strike the balance must depend on the kind of cross-border movement that has taken place. A distinction must be made between the different situations that can arise. ${ }^{139}$ While nonrecognition is easiest to justify in case of abusive practices (section D.II), it seems hard to see how a Member State can have a legitimate interest in not recognising the marriage of a visiting couple. Would the fictitious Dutch-Polish same-sex couple, referred to in the introduction, return to Poland for a quick visit, Poland should not be allowed to refuse to recognise this marriage. The most contentious as well as most complicated issue, however, seems to be the situation involving same-sex couples taking up residence in a Member State with strong public policies against same-sex marriages.

To balance the two competing legal claims at stake in such situations, proportionality appears to be the preferred legal tool. Problematically, however, the proportionality test is anything but a neutral arbiter in situations of conflict. Proportionality has been found to create a 'race to the top'

\footnotetext{
132 John Morijn, Balancing Fundamental Rights and Common Market Freedoms in Union Law: Schmidberger and Omega in the Light of the European Constitution, 12 European law Journal 15, 35-36 (2006). With respect to the interests that can be invoked, the EU closely resembles the US: Tobias Barrington Wolff, Interest Analysis in Interjurisdictional Marriage Disputes, 153 University of Pennsylvania Law Review 2215 (2005).

133 Eur. Court H.R., Dudgeon v the United Kingdom, Judgment of 22 October 1987, App no 7525/76; Eur. Court H.R Norris v Ireland, Judgment of 26 October 1988, App no 10581/83.

${ }^{134}$ See, for example: Eur. Court H.R., E.B. v France, Judgment of 22 January 2008, App no 43546/02; Eur. Court H.R. J.M. $v$ the United Kingdom, Judgment of 28 September 2010, App no 37060/06.

135 Eur. Court H.R., Vallianatos and Others v Greece, Judgment of 7 November 2013, App nos 29381/09 and 32684/09. ${ }^{136}$ Cloots (note 89) 285.

${ }^{137}$ Koppelman (note 11) chapter 4. Although one may argue that dignity requires the opening up of the institute of marriage to same sex couples. Arguments relating to dignity played a central role in the US Supreme Court's decision to legalise same-sex marriage in Obergefell $v$ Hodges (note 8).

138 Eur. Court H.R., Karner v Austria, Judgment of 24 July 2003, App no 40016/98, para 40; Vallianatos (note 135) para 83. See also: Eur. Court H.R., Schalk and Kopf v Austria, Judgment of 24 June 2010, App no 30141/04.

139 Koppelman (note 11) chapter 7.
} 
regarding the protection of rights. ${ }^{140}$ Furthermore, the test is prone to falling prey to normatively biased applications. It has been suggested, to give an example, that it allows "European judges, biased by the European market ideology, from deciding on sensitive matters which have their own ideology". ${ }^{141}$ According to Reich, the strict proportionality scrutiny in the free movement case law demonstrates the ECJ's tendency to at times adopt a "quasi-legislative approach". ${ }^{142}$ Would the free movement dimension of the same-sex cases result in a similarly strict scrutiny, a proportionality examination would risk "making a mockery of national autonomy", ${ }^{143}$ allowing centrally imposed 'European' norms to enter through the backdoor.

A more deferential proportionality analysis might be required to assure that the Court's judicial review respects pluralism. ${ }^{144}$ Such a lower intensity proportionality review has been proposed by de Witte, who has argued in favour of a more procedural version of the principle of proportionality. Accordingly, rather than examining the national measure's substantive content, such a procedural version focuses on the "coherence, consistency, and transparency" of the national policy. ${ }^{145}$ How such a proportionality review would play out is visible in some of the name cases. That the policy at stake in Sayn-Wittgenstein found its roots in Austria's constitutional identity will have had a decisive impact on the Court's decision to grant Austria a margin of appreciation. ${ }^{146}$ While the Member States are given a wider room of manoeuvre when their national and constitutional identity is at stake, the Court will take into account the consistency and coherency of a national measure when deciding whether or not to strike it down. That the Belgian decision in Garcia Avello was struck down was precisely because Belgium had not applied its policy consistently across the board. ${ }^{147}$ In addition, Member States are expected to produce clear evidence of the importance of their moral considerations. General and vague indications of the moral importance of a certain policy cannot suffice. ${ }^{148}$

A procedural proportionality test can provide for some guidance when determining whether to allow Member States not to recognise same-sex marriages legally celebrated in another Member State. One may expect, first of all, that Member States provide clear evidence of the fact that their argument for non-recognition is firmly grounded in considerations of national and constitutional identity. Member States should, moreover, be expected to apply their policy in a consistent and coherent manner for it not to be struck down. Would a Member State's policy of non-recognition be applied inconsistently, it appears questionable if the issue is of fundamental importance to a Member

\footnotetext{
140 MOSHE COHEN-ELIYA AND IDDO PORAT, PROPORTIONALITY AND CONSTITUTIONAL CULTURE (2013) $134-136$.

${ }^{141}$ Loïc Azoulai, The European Court of Justice and the Duty to Respect Sensitive National Interests, in JUDICIAL ACTIVISM AT THE EUROPEAN COURT OF JUSTICE (Mark Dawson, Bruno de Witte and Elise Muir eds., 2013 ) 179.

142 Norbert Reich, How Proportionate Is the Proportionality Principle? Some Critical Remarks on the Use and Methodology of the Proportionality Principle in the Internal Market Case Law of the ECJ, in THE EUROPEAN COURT OF JUSTICE AND THE AUTONOMY OF THE MEMBER STATES 105 (Hans-W Micklitz and Bruno de Witte eds., 2012). 143 de Witte (note 127) 1569.

144 Janneke Gerards, Pluralism, Deference and the Margin of Appreciation Doctrine, 17 European Law Journal 80 (2011).

145 de Witte (note 127) 1571.

${ }^{146}$ Sayn-Wittgenstein (note 84) para 87.

${ }^{147}$ Garcia Avello (note 28) para 44. The ECJ is not always consistent about its search for consistency though. Cloots (note 89).

${ }^{148}$ Case C-165/08 Commission v Poland [2009] E.C.R. I-6843, para 54.
} 
State's self-identification. It might be argued, against this, that all this achieves is that Member States adopt harsher policies, for example the adoption of constitutional provisions that clarify the importance of traditional marriage, or that they will consistently refuse to recognise same-sex marriages. This may be so, but is certainly not evident. It is far from certain, for example, if in today's climate, which seems somewhat more tolerant than a decade or so ago, the threshold for constitutional amendment can still be reached in those Member States that have not adopted any constitutional definition of marriage.

Even though providing for some guidance, a procedural proportionality test might not get us very far. It is very conceivable that a Member State's policy fulfils the requirements of a procedural proportionality test, but nonetheless produces grave and intolerable consequences, contrary to the rights enshrined in the ECHR. Even if Member States can justify non-recognition, they should not simply be allowed to refuse to provide access the same-sex partner of an EU citizen exercising the right to free movement. Returning to our fictitious example, this would mean the following: even if Greece can demonstrate that it has a sufficiently strong public policy against recognising same-sex marriages, it should still allow the Dutch-Polish same-sex couple to enter and reside there. It should not be allowed to prevent access to economically inactive partner on the ground that it does not recognise the partnership. That would be an unjustifiably severe burden to the right to free movement, which aim is more likely to punish homosexuality than protecting the constitutional understanding of marriage.

Understanding that extreme tension between the protection of national identity and the respect for fundamental rights, Cloots has suggested a pragmatic solution as a way out. Accordingly, Member States are under an obligation to "equate couples who got married in another Member State to "local" married couples, thus granting those couples the same rights but without registering them as "married" in national official documents". ${ }^{149}$ Unfortunately, this solution seems neither to respect a Member State's national identity, nor guarantees same-sex couples' fundamental rights. Cloots' suggestion seems to ignore, first of all, that the constitutional understanding of marriage is likely to include more than the status alone. A Member State might believe that certain rights, for example the right to adopt children, belong to this understanding and should, therefore, be reserved to heterosexual married couples. In addition, allowing Member States not to recognise a marriage may very well produce disproportionate consequences. This is particularly so in the case of parent-child relationships, the stability of which can be undermined by non-recognition. EU law should never allow children to end up in such a vulnerable situation. ${ }^{150}$

If there is a pragmatic solution to this problem, it seems one that achieves almost the opposite of what Cloots suggests. Koppelman in an analysis of a formerly ${ }^{151}$ very similar dilemma within the US has provided an alternative. To ensure the stability of the relationships and avoid the evasion of marital obligations, the right of States not to recognise a same-sex marriage should be constrained. However, to ensure respect for the diversity of moral and ethical norms, it should be allowed for them to reserve the rights they believe to belong to the institute of marriage to married heterosexual couples

\footnotetext{
${ }^{149}$ Cloots (note 100) 286 (italics omitted).

150 In relation to the debate in the US, this argument was made by:Koppelman (note 11) 109.

${ }^{151}$ See, supra, note 23.
} 
only. The latter implies that once States grant rights also to unmarried heterosexual couples, their scope should be extended so as to include same-sex couples as well. ${ }^{152}$ This solution appears to respect the limits set by the ECtHR, while also respecting the diverse set of national identities within the EU. By protecting same-sex couples and their relatives against the extreme hardship non-recognition may give rise and against their singling out by their placement in a position inferior to non-married opposite-sex couples, this suggestion would be less likely to violate the rights enshrined in the ECHR. Simultaneously, by allowing Member States to decide which rights to grant to married opposite-sex couples only, the EU would acknowledge the value plurality and diversity within the EU.

\section{F. Conclusion}

The world we are living in is not one that is indifferent to someone's sexual orientation. Unfortunate as this may be, it may be required, if we want to allow for diversity and disagreement, for the EU to accept practices incompatible with many of the liberal values which it promises to uphold. In pluralist societies, after all, there is a distinction between the ideas and practices incompatible with liberal principles and the question whether liberal ideas should be imposed on illiberal groups. ${ }^{153}$

Nevertheless, the capacity of the Member States not to recognise same-sex marriages celebrated in other Member States is very much constrained by the requirements imposed by EU law. As demonstrated in this article, Member States are under a presumption to recognise those same-sex marriages. This presumption can only possibly be refuted in case Member States have a strong public policy against same-sex marriages, which can be classified as going against their national and constitutional identity. However, even then are Member States required to respect the rights enshrined in the ECHR. Member States should be allowed to invoke their constitutional understanding of marriage, but this cannot justify bigoted policies that have nothing to do with such an understanding. The belief, held by some Member States, that marriage is inherently heterosexual cannot result in policies that interfere with or dissolve parent-child relationships. Neither is it proportionate, if nonrecognition is justifiable at all, to fully deny the same-sex couple the right to free movement.

All of this notwithstanding, the idea that EU law provides the magical formula whereby all injustices faced by moving same-sex couples will disappear is very questionable. EU law should leave room for and respect the plurality of values within the EU. As a consequence, it cannot be excluded that Member States can justify the non-recognition of a marriage or not provide same-sex couples with all the rights opposite-sex married couples benefit from. While EU law poses serious constraints

on Member States in this respect, it cannot be excluded completely that limitations to the free movement rights of same-sex couples can be justified.

\footnotetext{
152 Koppelman (note 11) 106-110.

153 WILL KYMLICKA, MULTICULTURAL CITIZENSHIP: A LIBERAL THEORY OF MINORITY RIGHTS 164 (1995).
} 